\title{
Woke Madness and the University
}

\section{Robert Leroux}

On college and university campuses, from where it emerged, the woke ideology has become a powerful instrument of censorship, a particularly clear manifestation of the intellectual terrorism that has reigned there for about half a century. ${ }^{1}$ In some cases, such as at Evergreen College in the State of Washington, it even encourages violence. In fact, woke culture is the intellectual plague of our times. Harvard linguist Steven Pinker strongly objects to it, arguing in many tweets and interviews that it is not based on facts and that, contrary to popular belief, racism is on the decline. ${ }^{2}$ Pinker has been severely criticized for his comments and accused of minimizing racial injustice. ${ }^{3}$ Hundreds of academics from the Linguistics Society of America signed a letter against him in July of 2020 containing the following words.

This is an open letter by members of the linguistics community calling for the removal of Dr. Steven Pinker from both our distinguished academic fellows and our list of media experts. We, the undersigned, believe that Dr. Pinker's behavior as a public academic is not befitting of a representative of our professional organization, that the LSA's own stated goals make such a conclusion inevitable, and that the LSA should publicly reaffirm its position and distance itself from Dr. Pinker.

And they add:

1 What Jean Sévillia says about intellectual terrorism can be applied mutatis mutandis to the woke doctrine. "It is a totalitarian system. It is an insidious totalitarianism. It aims to take the floor away from the opponent, who has become a beast to be slaughtered. To be killed without spilling blood: only by letting words burst out. The words of great conscience. The words that kill." Jean Sévillia, Le terrorisme intellectuel (Paris: Perrin, 2004, 10)

2 Mark Bauerlein, "Unlearning liberty: campus censorship and the end of American debate", Academic Questions 26, no. 2 (2013): 99-105.

3 Steven Pinker, "Aujourd'hui, cette folie woke est l'affaire de tous," L'Express, March 3, 2021; see: Enlightenment Now: The Case for Reason, Science, Humanism and Progress (New York: Viking, 2018).

Robert Leroux is Full Professor of Sociology at the University of Ottawa; roleroux@uottawa.ca. 
Dr. Pinker has a history of speaking over genuine grievances and downplaying injustices, frequently by misrepresenting facts, and at the exact moments when Black and Brown people are mobilizing against systemic racism for crucial changes." ${ }^{4}$

We must say that what we now call the woke culture or movement is nothing new. It is part of a long tradition, influenced by Marxism, feminism, relativism, etc. It is not a scientific approach to reality, but essentially an ideological posture, an attitude, a social movement. The situation is getting worst because most academics are now activists.

As early as the 1980s, in his seminal book The Closing of the American Mind, Allan Bloom analyzed this phenomenon in its first manifestations before the word woke was coined.

It became almost impossible to question the radical orthodoxy without risking vilification, classroom disruption, loss of the confidence and respect necessary for teaching, and the hostility of colleagues. Racist and sexist were, and are, very ugly labels-the equivalents of atheist or communist in other days with other prevailing prejudices-which can be pinned on persons promiscuously and which, once attached, are almost impossible to cast off. Nothing could be said with impunity. Such an atmosphere made detached, dispassionate study impossible." ${ }^{5}$

For Bloom, it became almost impossible to question extremist orthodoxy without running the risk of being vilified as an intolerant person. The situation today is not really different.

One could find similar analyses in the 1990s by Dinesh D'Souza who was troubled by life on campus. According to him, minorities exert pressure within colleges and universities. They taught that "all rules are unjust," that standards are arbitrary, and the "ideal of an educated person is largely a figment of bourgeois white male ideology, which should be cast aside.” ${ }^{6}$ D'Souza was right on target when he said that

4 Michal Powell, "How Famous Harvard Professor Became a Target Over His Tweets," New York Times, July 15,2020 .

5 Allan Bloom, The Closing of the American Mind (New York: Simon \& Schuster, 1987), 355.

6 Dinesh D'Souza, Illiberal Education: The Politics of Race and Sex on Campus (New York: Free Press, 1991), 229. 
the academic and cultural revolution is underway at American universities. It is revising the rules by which student are admitted to college, and by which they pay for college. It is changing what students learn in the classroom, and how they are taught. It is altering the structure of life on campus including habits and attitudes of students in residence. ${ }^{7}$

New generations of professors have been hired not because they are concerned with and dedicated to science and objective knowledge, but because they are mainly political activists. Everything is wrong with the woke ideology: extreme paranoia, a mistaken view of social life, free speech, and the common man. Listening to the doctrinaires of the woke movement, we see that we are entering an unreal world, based on exaggerations, resolutely closed to dialogue and debate.

With wokeness, we cannot have a better example of the extreme radicalization of the left. The left which was once devoted to the fate of the working class and its struggles belongs to a bygone past. At the University of Ottawa, on a job posting one can read this:

The Institute of Feminist and Gender Studies at the University of Ottawa, located on the traditional and unceded territory of the AnishinabeAlgonquin people, is accepting applications for one tenure-track position in Afro-feminist studies. Applications from people who work with an intersectional framework on Islamophobia and anti-black racism, solidarities between Black and Indigenous people, transnational feminisms, Black feminist methodologies and practices, queer of colour or black trans studies and/or the history and impacts of slavery in Francophone contexts, are particularly welcome. Community experience is an asset, as is bilingualism . . . Qualified Black applicants from Africa or the African diaspora (descended from the Caribbean, North America, Europe, Latin America, etc.) are invited to apply for this position.

The description is ridiculous. Everything is there: Islamophobia, queer, transgender. It is clear that the University of Ottawa is not looking for a real 
social scientist, devoted to rigorous, objective scholarship. It would be clearer if the posting read: "Men (and even white women) need not apply; university set to open job just for black or queer women.”

From a scientific standpoint, it is absurd to call for "black feminist methodology." One might have thought this was a caricature intended only to provoke hilarity. But behind this pernicious ideological plague, for which the University of Ottawa has made itself a zealous advocate, an essential thing emerges: being part of a minority group is not only an advantage but a virtual necessity for anyone who wishes to embrace an academic career. And like many North American universities, the $\mathrm{U}$ of $\mathrm{O}$ will lower standards to further minority group advantage.

Lawrence Watson, an administrator at Harvard, is convinced that his university must modernize in light of minorities' demands. His penchant for activism makes him a true guide. The purpose of programs such as African American studies or gender studies is not to produce real knowledge, but "to capture the fact that we still live in a society of blatant racism." In fact, "racism has become institutionalized." It is therefore unnecessary to read what are called great works because they supposedly do not do justice to women and minorities. However, in the name of sensitivity, Harvard does not seem to hesitate to distort the truth and to spread information which is clearly untrue. Harvard talks unreservedly about "institutional racism," a concept that seems to defy clear definition, never requires evidence, and is at any rate hotly contested. Positive discrimination in favor of protected groups has become a secular religion among the woke. Either way, the reign of the aggrieved victim is opening up; administrators slavishly submit to it.

Wokeness views the world today with great disdain, indeed hates it bitterly. Not only must social distinctions disappear, it is, above all, important that politicized racial, sexual, and gender groups impose their interests and their vision on the world.

Like Marxism, this doctrine delivers the individual to servitude: we flout him, we censor him, we impose a new vocabulary on him, even a new way of thinking. It is clear that many universities have become liberticidal. 